\title{
RELAÇÃO ENTRE A TOPOGRAFIA DE LESÕES DE PELE E O PERFIL SOCIODEMOGRÁFICO EM UMA CIDADE RURAL DE SANTA CATARINA
}

Gigliolle Romancini de Souza Acadêmica do Curso de Medicina, Universidade do Extremo Sul Catarinense, giglioller@gmail.com Cíntia Manzoni Acadêmica do Curso de Medicina, Universidade do Extremo Sul Catarinense, cicimanzoni85@gmail.com

Kristian Madeira

Doutor, Universidade do Extremo Sul Catarinense, kma@unesc.net

Luiz Felipe de Oliveira Blanco Dermatologista, Universidade do Extremo Sul Catarinense, lfobpoa@yahoo.com.br

\section{RESUMO}

O câncer de pele é a neoplasia maligna mais comum em várias regióes do mundo e representa um problema de saúde pública. Sua incidência aumenta entre indivíduos de pele clara. Dessa forma, uma população agrícola, predominantemente de descendência italiana, apresenta maior susceptibilidade ao dano solar. $\mathrm{Na}$ região sul, esse perfil epidemiológico é encontrado. Neste estudo, objetivou-se avaliar a relação entre a topografia de lesóes de pele e o perfil sociodemográfico de habitantes de uma cidade rural de Santa Catarina, no período de julho a outubro de 2015. A pesquisa é um estudo observacional transversal de abordagem quan- 
titativa, que foi realizada em uma cidade pertencente à microrregião do extremo sul catarinense. As variáveis avaliadas foram idade, gênero, profissão e o local das lesóes. A análise estatística foi realizada com o uso do software Statistical Package for the Social Sciences (SPSS), versão 22.0, e confiança de 95\%. Avaliaram-se 99 indivíduos adultos. No sexo feminino, houve uma maior prevalência de lesóes localizadas em tronco $(p=0,029)$ e pernas $(p=0,028)$; enquanto, no sexo masculino, as lesóes foram mais presentes na orelha $(\mathrm{p}=0,015)$. A idade avançada esteve relacionada às lesóes localizadas em lábios $(\mathrm{p}=0,048)$ e braços $(\mathrm{p}=0,009)$. Lesóes localizadas no nariz estiveram fortemente relacionadas à profissáo agrícola $(89,7 \%, n=26 ; p=0,005)$. Acredita-se que lesóes localizadas em tronco e pernas tenham sua maior prevalência em mulheres devido ao vestuário utilizado e a menor quantidade de pelo corporal. Já a menor prevalência de lesóes em orelha, no sexo feminino, pode estar relacionada ao efeito protetor do cabelo comprido sobre o pavilhão auricular (CORREA et al., 2012). As lesóes de localização em lábios e membros superiores tiveram uma prevalência maior em indivíduos de idade avançada, podendo isso estar relacionado a um sistema imunológico menos eficiente e a uma menor capacidade de reparação do DNA (BARIANI et al., 2006). Lesóes localizadas no nariz estiveram fortemente ligadas à profissão agrícola, pois tal fato pode estar diretamente ligado à forte exposição solar (ATTARCHI et al., 2009). A topografia de lesões de pele está fortemente relacionada a aspectos sociodemográficos. Dessa forma, apropriar-se destes conhecimentos é fundamental para o planejamento de medidas preventivas.

Palavras-chave: Pele; Condiçóes Socioeconômicas; Topografia.

\section{REFERÊNCIAS}

ATTARCHI, M. et al. Evaluation of skin diseases and disorders in photographers. Indian Journal of Occupational and Environmental Medicine [online], v.13, n.2, p.88-91, 2009.

BARIANI, R. L. et al. Basal cell carcinoma: an updated epidemiological and therapeutically profile of an urban population. Acta Cirúrgica Brasileira, São Paulo, v.21, n.2, p.66-73, 2006. 
CORREA, L. H. L. et al. Epidemiologia dos carcinomas espinocelulares na população atendida em Tubarão (SC), entre 1999 e 2009. Anais Brasileiros de Dermatologia, Rio de Janeiro, v.87, n.4, p.572-577, 2012. 